\title{
Pemberdayaan Masyarakat Melalui Gerakan Literasi Perdesaan di Desa Cimanggu Kabupaten Bandung Barat
}

\author{
Dian Herdiana ${ }^{1}$, Rendi Heriyana ${ }^{2}$, Reza Suhaerawan ${ }^{2}$ \\ 1,2 Sekolah Tinggi Ilmu Administrasi (STIA) Cimahi
}

\begin{abstract}
Article History ABSTRACT
Received 29.08.2019

Received in revised form 04.10.2019

Accepted 04.12.2019

Available online 16.12.2019

COMMUNITY EMPOWERMENT THROUGH RURAL LITERACY MOVEMENT IN CIMANGGU VILLAGE, BANDUNG BARAT DISTRICT. The community in Cimanggu Village, Bandung Barat District has a low literacy culture. This is due to various factors starting from the factor of the village government that does not support the literacy movement aimed at policy instruments, the cultural factors of the community who regard literacy as not a necessity and the factors that come from academics who do not disseminate information about the importance of literacy. Based on the above problems, the students of Cimahi School of Public Administration (STIA Cimahi) in the community engagement service launched a program in the form of rural literacy movement. To realize this, various activities were carried out starting from visits to village governments to encourage literacy policy at the village level. Conducting counselling to the community about the importance of literacy. Conducting literacy activities in children's play environment that encourage children to make literacy activities a necessity and culture, as well as renovating a library in the village office to make it easier for the community to access literacy infrastructure in the village.
\end{abstract}

KEYWORDS: Community Empowerment, Reading Culture, Rural Literacy.

\section{PENDAHULUAN}

Literasi yang ada di Indonesia masih belum menjadi sebuah budaya yang dianggap sebagai sebuah kebutuhan (Suragangga, 2017). Survei yang dilakukan oleh UNESCO pada tahun 2016 mengenai budaya membaca yang ada di negara-negara ASEAN menempatkan Indonesia sebagai negara yang memiliki budaya membaca paling rendah dengan nilai 0,001. Hal ini mengandung artian dari 1000 (seribu) orang penduduk hanya 1 (satu) orang yang gemar membaca (Nopilda \& Kristiawan, 2018).

Minimnya budaya literasi juga dialami oleh generasi muda yang masih dalam proses pendidikan, bahkan salah satu kajian menunjukan bahwa anak-anak Indonesia hanya

${ }^{1}$ Corresponding author: Program Studi Administrasi Negara, Sekolah Tinggi Ilmu Administrasi (STIA) Cimahi; Jalan Raya Cibeber Nomor 148 Kota Cimahi, Indonesia. Email: kyberdian@gmail.com 
membaca buku sebanyak 17 halaman selama satu tahun atau 1 (satu) halaman dalam setiap 2 (dua) minggu (Wandasari, 2017). Hal ini tentu menjadi keprihatinan bahwa generasi muda yang diharapkan mampu menjadi generasi yang unggul secara praktis tidak memiliki budaya literasi yang baik dan tidak menganggap literasi akan mampu membawa perbaikan bagi individu yang bersangkutan maupun bagi masyarakat di masa yang akan datang.

Kondisi tersebut sejalan dengan fakta empiris yang mana perkembangan teknologi informasi yang pesat tidak meningkatkan minat literasi masyarakat. Berbagai referensi seperti buku, jurnal, media masa yang sudah berbentuk digital dan mudah diakses oleh masyarakat belum mampu menggugah keinginan masyarakat untuk mau membaca, mengetahui dan memahami ilmu pengetahuan. Bahkan terdapat kecenderungan mudahnya akses informasi secara digital disalah gunakan menjadi tindakan yang tidak patut seperti penyebaran berita bohong (hoax), penyebaran kebencian dan SARA atau Suku, Agama, Ras dan Antar Golongan (Miskahuddin, 2017; Ritonga \& Andhika, 2012).

Literasi apabila dikaji secara mendalam tidak hanya diartikan sebagai literate (melek hurup), tetapi juga diartikan sebagai praktik-praktik dalam sebuah situasi sosial, sejarah dan budaya dalam rangka menciptakan dan mengartikan (interprete) makna melalui teks (Kern dalam Marfu 'i, 2016). Apabila makna ini diterapkan, maka kemampuan literasi seyogyanya mampu membendung berita palsu (hoax) dan konten-konten negatif lainnya secara elektronik dikarenakan masyarakat yang memiliki budaya literasi akan mampu menyaring berbagai informasi yang dihadapkan kepadanya (Rohidin, 2012).

Pemahaman tersebut di atas menkonstruksikan pemahaman bahwa literasi memiliki peran yang penting baik bagi kehidupan pribadi, masyarakat juga bagi negara, sehingga gerakan literasi perlu diupayakan oleh semua pihak baik secara individu, secara berkelompok maupun secara nasional melalui instrumen kebijakan literasi nasional (Andina, 2017; Permatasari, 2015)

Atas dasar pentingnya meningkatkan literasi masyarakat sekaligus menjadikan literasi sebagai sebuah budaya, maka dalam kegiatan pengabdian kepada masyarakat, mahasiswa Sekolah Tinggi Ilmu Administrasi (STIA) Cimahi Angkatan 2016 menyusun rencana gerakan literasi perdesaan sebagai salah satu program yang didasarkan atas kewajiban kalangan akademisi untuk turut serta menjadikan literasi sebagai budaya yang ada di masyarakat perdesaan.

Masyarakat yang ada di Desa Cimanggu Kecamatan Ngamprah Kabupaten Bandung Barat belum menjadikan literasi sebagai budaya dalam kehidupan sehari-hari. Berdasarkan kepada observasi yang dilakukan, minimnya literasi yang ada disebabkan oleh beberapa faktor, yaitu: Pertama, faktor pemerintah khususnya Pemerintah Desa Cimanggu yang kurang mendukung gerakan budaya literasi, hal ini ditujukan baik melalui instrumen kebijakan yang tidak menjadikan literasi sebagai bagian dari kebijakan pembangunan desa, maupun minimnya ketersediaan sarana infrastruktur penunjang literasi seperti tidak adanya perpustakaan desa.

Kedua, faktor masyarakat yang beranggapan literasi merupakan kewajiban bagi anak dan remaja yang sedang menuntut ilmu, masyarakat menganggap bahwa literasi tidak dibutuhkan dan bukan merupakan bagian dari budaya masyarakat. Ketiga, kalangan akademisi baik itu yang berasal dari institusi sekolah yang berada di lingkungan desa maupun warga masyarakat desa yang berlatar belakang sebagai akademisi kurang 
memberikan sosialisasi maupun penyuluhan kepada masyarakat akan pentingnya literasi yang ada di desa.

Permasalahan yang didapat melalui observasi tersebut oleh mahasiswa dijadikan sebagai masukan dalam upayanya mencari solusi atas minimnya budaya literasi yang ada di Desa Cimanggu. Kegiatan gerakan literasi perdesaan secara umum ditujukan untuk meningkatkan minat masyarakat sekaligus menjadikan literasi sebagai bagian dari budaya masyarakat desa. Adapun sasaran dan tujuan program yang ingin di capai yaitu: Pertama, kelompok sasaran yang berasal dari pemerintah yaitu dengan adanya gerakan literasi perdesaan diharapkan mampu menggugah Pemerintah Desa Cimanggu akan pentingnya literasi dan menjadikan literasi sebagai bagian dari kebijakan pembangunan desa yang akan dilaksanakan sehingga akan dibangunnya infrastruktur yang menunjang literasi seperti perpustakaan desa.

Kedua, kelompok sasaran masyarakat diharapkan mampu menggugah kesadaran dan menumbuhkan minat baca sehingga akan menciptakan budaya literasi yang akan memberikan manfaat baik secara langsung maupun tidak langsung bagi kehidupan masyarakat. Dengan tingginya kesadaran literasi di masyarakat maka diharapkan akan mendorong untuk mendidik anak-anaknya agar memiliki budaya literasi, sehingga menjadikan literasi sebagai sebuah tuntutan dan kebutuhan.

Ketiga, bagi kalangan akademisi khususnya pemangku kepentingan di sekolah yang berada di lingkungan Desa Cimanggu dapat menumbuhkan minat siswa terhadap literasi, sehingga mampu melahirkan generasi muda yang menjadikan literasi sebagai kebutuhan dan bagian dari kehidupan generasi muda.

Ketiga tujuan di atas diwujudkan dalam berbagai kegiatan dalam program gerakan literasi perdesaan yang didasarkan kepada kelompok sasaran yang telah dijelaskan tersebut di atas. Sehingga kehadiran mahasiswa dalam kegiatan pengabdian kepada masyarakat tidak hanya mampu mendorong dan memfasilitasi masyarakat dalam konteks pembangunan infrastruktur semata, tetapi juga mampu berkontribusi dalam bentuk social capital yang diharapkan akan memberikan manfaat dalam waktu yang lama.

\section{METODE PELAKSANAAN}

Metode yang digunakan yaitu Participatory Rural Appraisal (PRA) yang mana metode PRA didefinisikan sebagai metode dalam proses pemberdayaan masyarakat dengan menekankan kepada partisipasi aktif masyarakat dalam keseluruhan proses yang sedang dilaksanakan mulai dari tahap awal berupa perencanaan kegiatan sampai dengan tahap akhir berupa evaluasi dan penerimaan manfaat bagi masyarakat (Adimiharja \& Hikmat, 2003; Pratiwi, 2007).

Data yang diperoleh dengan menggunakan metode PRA tidak akan persis sama antara satu peneliti dengan peneliti lainnya, hal ini menjadi bukti akan beragamnya hasil informasi yang didapat dari masyarakat (Handayani, 2009). Meskipun demikian, perbedaan data yang diperoleh akan memberikan perspektif yang berbeda yang pada akhirnya akan melahirkan kesinambungan antar hasil penelitian.

Adanya penggunaan metode PRA ini maka masyarakat ditempatkan sebagai subjek sekaligus objek dalam program gerakan literasi perdesaan. Masyarakat dilibatkan sejak awal mulai dari penyusunan kebutuhan program seperti merencanakan waktu kegiatan yang disesuaikan dengan aktivitas sekolah anak-anak, kebutuhan literasi seperti buku 
dan bahan bacaan apa yang sesuai dengan kebutuhan masyarakat sasaran sampai dengan menetapkan tujuan dan manfaat dari adanya program tersebut. Sedangkan posisi masyarakat bersifat inklusif yang menjadi bagian dalam kegiatan literasi perdesaan yang mengarahkan dan memberi petunjuk teknis agar kegiatan gerakan literasi perdesaan dapat berjalan sebagaimana yang diharapkan.

Tahapan kegiatan yang dilakukan dalam program gerakan literasi perdesaan dilakukan melalui 3 (tiga) tahapan yang meliputi tahap persiapan, tahap pelaksanaan dan tahap evaluasi. Adapun penjelasan ketiga tahapan tersebut sebagai berikut:

\section{Tahap Persiapan}

Tahap persiapan terdiri dari 3 (tiga) kegiatan yaitu: Pertama, melakukan observasi mengenai kondisi literasi yang ada di Desa Cimanggu, bagaimana minat dan budaya baca masyarakat serta faktor apa saja yang menjadi penghambat dan dapat menjadi pendorong untuk meningkatkan kegiatan literasi perdesaan. Kedua, pemetaan masalah dan potensi dari data yang telah dikumpulkan melalui observasi yang telah dilakukan sebelumnya. Ketiga, melakukan penyusunan program kegiatan setelah memperoleh pemetaan dan potensi mengenai kegiatan literasi perdesaan. Dalam ketiga tahap tersebut mahasiswa melibatkan masyarakat agar terjadi proses komunikasi dua arah dan memunculkan kesepahaman dengan masyarakat.

\section{Tahap Pelaksanaan}

Berbagai kegiatan yang telah disusun dalam tahap persiapan mulai dilaksanakan dengan mengajak para aktor kepentingan untuk secara bersama-sama berpartisipasi menyukseskan berbagai kegiatan yang telah disusun. Adapun uraian kegiatan pelaksanaan terdiri dari:

\section{Sosialisasi}

Mahasiswa dan masyarakat dituntut untuk mengetahui program yang akan dilaksanakan beserta peran masing-masing, oleh sebab itu dilaksanakan sosialisasi baik secara internal kepada pemangku kepentingan yang terlibat secara langsung maupun sosialisasi eksternal yang dilakukan kepada kelompok masyarakat sasaran program gerakan literasi perdesaan.

\section{Pelatihan}

Pelatihan ditujukan agar pelaksana yang dalam hal ini merupakan mahasiswa mengetahui tugas masing-masing, sehingga selain agar tidak menimbulkan tumpang tindih pekerjaan antara satu orang dengan yang lainnya juga ditujukan agar kegiatan dapat dilaksanakan sebagaimana maksud yang telak ditetapkan di awal.

\section{Pendampingan}

Mahasiswa yang ditunjuk melakukan pendampingan bagi para pelaksana kegiatan agar proses pelaksanaan kegiatan literasi perdesaan berjalan sesuai dengan pedoman yang telah ditetapkan. Kegiatan pendampingan dilaksanakan dalam keseluruhan kegiatan yang dilakukan dan menjadi bagian dari gerakan literasi perdesaan.

\section{Tahap Evaluasi}

Kegiatan yang telah dilaksanakan harus dilakukan penilaian untuk melihat tingkat keberhasilan yang dicapai dari program literasi perdesaan tersebut. Kegiatan evaluasi 
meliputi seluruh penilaian proses dari awal sampai dengan akhir serta melihat dampak atau manfaat yang dirasakan oleh masyarakat dengan adanya kegiatan literasi perdesaan yang telah dilaksanakan tersebut.

\section{HASIL DAN PEMBAHASAN}

Pelaksanaan kegiatan pengabdian kepada masyarakat melalui program gerakan literasi perdesaan dilaksanakan di Desa Cimanggu Kecamatan Ngamprah Kabupaten Bandung Barat selama 2 (dua) bulan dari bulan Juli 2019 sampai dengan bulan Agustus 2019. Kegiatan pelaksanaan gerakan literasi perdesaan yang dilakukan oleh Mahasiswa STIA Cimahi di Desa Cimanggu dapat dijelaskan sebagai berikut:

\section{Sosialisasi dan Advokasi Gerakan Literasi Perdesaan Kepada Pemerintah Desa}

Gerakan literasi perdesaan harus mendapatkan dukungan dari berbagai pihak, terutama dari pemerintah desa. Hal ini dikarenakan pemerintah desa sebagai pemegang kewenangan penyelenggaraan pemerintahan di tingkat desa. Salah satu wujudnya dapat berupa pemberian dukungan kepada gerakan literasi perdesaan yang tidak hanya ditujukan kepada kebijakan pembangunan infrastruktur literasi perdesaan tetapi juga dukungan dalam menggerakan masyarakat untuk berpartisipasi dalam gerakan literasi perdesaan tersebut.

Atas dasar permasalahan tersebut maka mahasiswa dalam melaksanakan program literasi perdesaan yaitu mengunjungi pemerintah desa terlebih dahulu sebelum kelompok sasaran lainnya. Dalam kunjungan tersebut pemerintah desa yang dipimpin langsung oleh Kepala Desa menerima mahasiswa yang menyampaikan mengenai arti penting literasi perdesaan yang ada di Desa Cimanggu. Tanggapan yang diberikan pihak pemerintah desa secara umum mengapresiasi adanya gerakan literasi perdesaan yang digagas oleh mahasiswa dalam rangkaian program pengabdian kepada masyarakat.

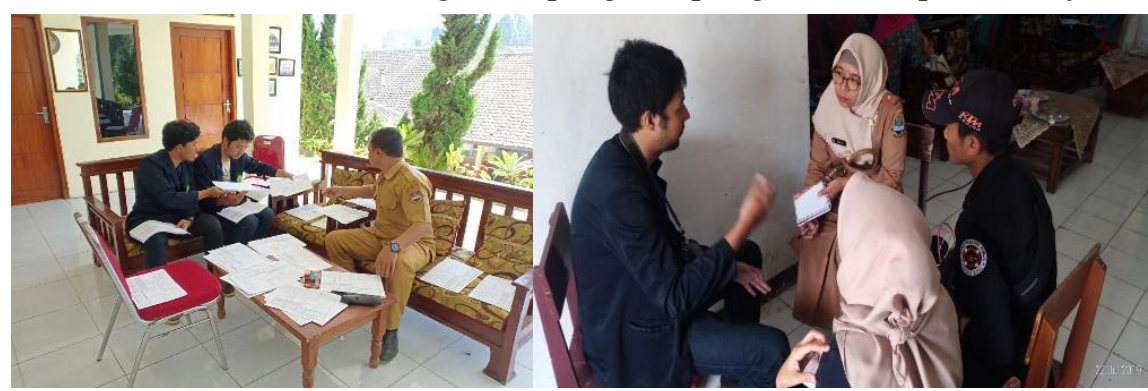

Gambar 1. Kegiatan Mahasiswa dengan Aparat Pemerintah di Desa Cimanggu

Lebih lanjut pihak pemerintah desa memaparkan mengenai berbagai permasalahan mengenai literasi perdesaan yang ada di desanya, salah satu permasalahan yang coba diselesaikan oleh mahasiswa yaitu mengaktifkan kembali perpustakaan desa yang hampir satu tahun tidak beroperasi. Komitmen pemerintah desa lainnya yaitu akan mendukung setiap kegiatan literasi perdesaan yang dilaksanakan dalam program pengabdian kepada masyarakat dan akan mendorong pihak lainnya untuk turut berpartisipasi dalam kegiatan tersebut.

Hasil sosialisasi gerakan literasi perdesaan kepada pemerintah desa dapat dikatakan berhasil, hal ini dibuktikan selain kepada dukungan secara moral dan memfasilitasi 
penyelenggaraan gerakan literasi perdesaan, pemerintah desa juga turut menginstruksikan aparat pemerintah desanya untuk membantu menyukseskan gerakan literasi perdesaan tersebut seraya didukung dengan sumbangan fisik seperti penyediaan buku dan sarana lainnya yang dibutuhkan dalam gerakan literasi perdesaan.

\section{Penyuluhan Gerakan Literasi Perdesaan bagi Masyarakat}

Gerakan literasi perdesaan yang ditujukan bagi masyarakat salah satunya dengan mengajak anggota Pembina Kesejahteraan Keluarga (PKK) yang beranggotakan ibu-ibu dari Desa Cimanggu sebagai penggerak dan sasaran penyuluhan gerakan literasi perdesaan. Anggota PKK merupakan perhimpunan yang aktif untuk menyosialisasikan berbagai program desa khususnya yang berkenaan dengan program masyarakat dan keluarga. Dengan begitu diharapkan dengan adanya penyuluhan gerakan literasi perdesaan kepada ibu-ibu anggota PKK diharapkan akan mampu menumbuhkan kesadaran akan pentingnya literasi yang nantinya tidak hanya akan menyosialisasikan kepada anggota keluarganya, khususnya anak-anak, tetapi juga gerakan literasi perdesaan akan mampu menjadi program dari PKK.

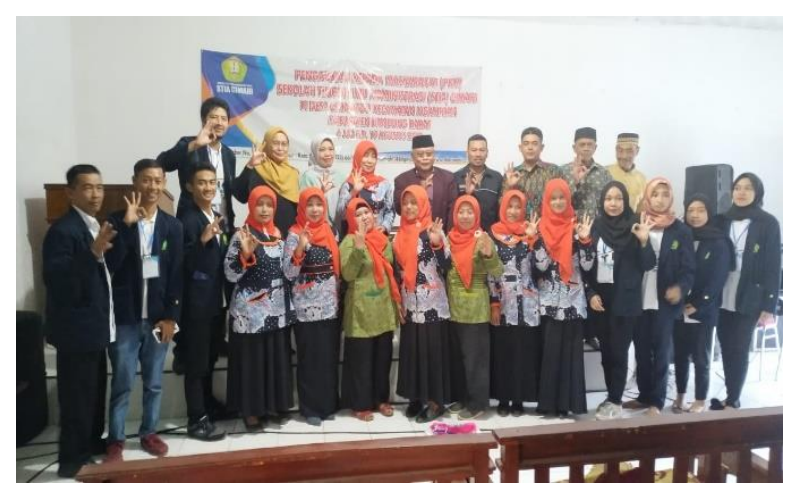

Gambar 2. Mahasiswa beserta Anggota PKK Desa Cimanggu

Tahap pertama pelaksanaan penyuluhan literasi perdesaan kepada anggota PKK yaitu dengan berbicara kepada ketua PKK mengenai tujuan dari pelaksanaan gerakan literasi perdesaan. Tanggapan yang diberikan oleh Ketua PKK yaitu mendukung sepenuhnya gerakan literasi perdesaan dan memberitahukan kepada anggota PKK untuk turut serta secara aktif dalam kegiatan tersebut.

Selama proses penyuluhan berlangsung, anggota PKK memiliki minat untuk melaksanakan kegiatan literasi perdesaan. Anggota PKK menyadari bahwa literasi merupakan kegiatan yang baik dan bahkan harus dijadikan sebagai budaya khususnya bagi anak-anak yang ada di desa. Anggota PKK menyatakan bahwa gerakan literasi harus senantiasa digalakan oleh setiap unsur yang ada di desa agar dapat memberikan manfaat yang banyak kepada masyarakat. Meskipun demikian anggota PKK menyatakan bahwa gerakan literasi tidak akan mudah diterapkan dan akan dihadapkan kepada berbagai permasalahan.

Permasalahan terbesar dalam gerakan literasi perdesaan yang ada di Desa Cimanggu yaitu harus dihadapkan kepada kondisi sosial kemasyarakatan yang ada di desa yang tidak kondusif bagi gerakan literasi perdesaan. Salah satu anggota PKK menyatakan bahwa mata pencaharian masyarakat yang bercocok tanam yang mana sebagian dari masyarakat sudah berada di ladang dari pagi hingga sore dan tidak 
memiliki kesempatan untuk melakukan gerakan literasi yang dilaksanakan akan menjadi indikator bahwa masyarakat akan sedikit yang menaruh perhatian akan permasalahan literasi perdesaan. Di satu sisi, sikap masyarakat dianggap wajar dikarenakan pekerjaan utama untuk berkebun merupakan hal yang harus didahulukan.

Atas dasar pemahaman tersebut maka mahasiswa tidak menetapkan harapan yang tinggi akan perubahan sikap masyarakat akan gerakan literasi perdesaan. Adanya pelaksanaan program yang dilakukan mahasiswa harus senantiasa berasal dari kebutuhan masyarakat, sehingga program tersebut memiliki potensi yang besar untuk berhasil, hal ini dikarenakan masyarakat desa memiliki karakter untuk berpartisipasi dalam kegiatan yang memiliki keterkaitan langsung dengan mata pencahariannya (Herdiana, 2018).

Permasalahan lainnya dalam gerakan literasi perdesaan yaitu pandangan masyarakat yang memandang bahwa gerakan literasi tidak memiliki korelasi dengan pekerjaan mereka sehari-hari, sehingga literasi oleh sebagian besar masyarakat dipandang akan tepat apabila diterapkan bagi anak-anak yang masih berada di bangku sekolah, bukan kepada masyarakat yang sehari-harinya bekerja di ladang.

Sebagian anggota PKK memiliki latar belakang sebagai tenaga pendidik di sekolah yang ada di Desa Cimanggu, sehingga kegiatan tersebut sekaligus dijadikan ajang untuk memberikan penyuluhan kepada kalangan akademisi agar kegiatan literasi yang ada di sekolah-sekolah digalakan dan ditingkatkan agar menjadi sebuah gerakan yang memberikan manfaat bagi anak-anak.

Dari kegiatan sosialisasi dan penyuluhan gerakan literasi perdesaan yang dilakukan kepada anggota PKK, maka didapat hasil bahwa sebagian besar anggota PKK menyatakan dukungan dalam gerakan literasi perdesaan dan menyadari akan pentingnya literasi, meskipun demikian gerakan literasi perdesaan yang dilakukan dinilai tepat bagi anak-anak yang masih duduk di bangku sekolah, sedangkan untuk masyarakat umum yang ada di desa kurang tepat dikarenakan mata pencaharian mereka sebagai petani tidak memiliki korelasi langsung dengan gerakan literasi perdesaan yang dilakukan di desa.

\section{Penyuluhan Gerakan Literasi di Lingkungan Bermain Anak-Anak}

Anak-anak merupakan sasaran yang ideal dalam gerakan literasi perdesaan, hal ini dikarenakan aktivitas mereka yang dalam proses belajar memerlukan berbagai referensi guna menunjang pengetahuan mereka. Adanya sikap yang menjadikan literasi sebagai sebuah kebutuhan dan budaya akan memberikan banyak manfaat bagi anak-anak dan pemuda (Irianto \& Febrianto, 2017).

Seiring dengan perkembangan teknologi informasi memberikan berbagai kemudahan kepada anak-anak dan pemuda untuk mengakses literasi yang tidak hanya secara tradisional dimana mereka mendatangi perpustakaan atau membeli buku yang menunjang proses belajar mereka. Berbagai buku elektronik dan bahan bacaan lainnya tersedia secara daring (online), baik itu yang disediakan oleh pemerintah maupun oleh organisasi swasta dan bisnis (Akbar \& Anggraeni, 2017; Silvana \& Cecep, 2018). 


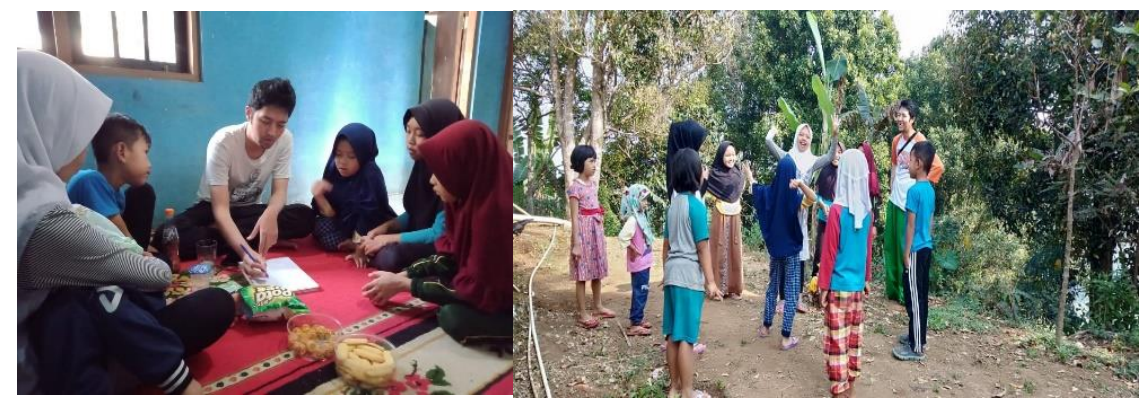

Gambar 3. Kegiatan Literasi dengan Anak-Anak di Desa Cimanggu

Berdasarkan kepada fakta empiris di Desa Cimanggu dapat dikatakan bahwa anakanak kurang memanfaatkan literasi secara digital untuk meningkatkan pengetahuan dan menunjang pembelajaran mereka. Anak-anak justru memanfaatkan akses internet sebagai tempat mereka bermain dan mencari hiburan seperti dipergunakan untuk bermain game online atau aktif dalam situs jejaring sosial seperti facebook dan instragram.

Kondisi seperti ini sejalan dengan beberapa pendapat pakar seperti Lombogia, Kairupan, dan Dundu (2018); Sari, Ilyas, dan Ifdil (2017); Zaidannas (2017) yang semua sependapat menyebut bahwa akses internet tidak benar-benar dimanfaatkan oleh anakanak dan masyarakat untuk memperoleh informasi dan pengetahuan. Bahkan internet memiliki dampak buruk bagi anak-anak dan pemuda yang salah satunya menurunkan minat mereka untuk belajar dan memberikan sifat kecanduan terhadap konten negatif.

Kegiatan yang dilakukan oleh mahasiswa untuk menggugah ketertarikan kepada literasi yaitu mengajak anak-anak yang ada di Desa Cimanggu untuk secara bersamasama belajar dan bermain. Kegiatan belajar dan bermain dilakukan di posko mahasiswa yang mengundang anak-anak secara sukarela untuk datang. Kegiatan tersebut rutin dilaksanakan setelah anak-anak pulang dari sekolah sampai dengan sore hari.

Hasil dari gerakan literasi terhadap anak-anak di Desa Cimanggu dinilai berhasil dikarenakan banyak anak yang secara intens mengikuti proses belajar dan bermain yang dipandu oleh mahasiswa sesuai dengan bidang ilmu dan keahliannya masing-masing, serta mampu meningkatkan minat anak-anak untuk membaca dan belajar setiap hari.

\section{Memperbaiki Taman Bacaan Masyarakat}

Perpustakaan desa tidak hanya berperan sebagai tempat bagi masyarakat memperoleh informasi, tetapi juga dapat membangun nilai sosial, nilai sejarah dan nilai lainnya yang ada di masyarakat (Alam, 2015; Rohman \& Sukaesih, 2017; Yusup \& Saepuddin, 2017). Oleh sebab itu keberadaan perpustakaan desa perlu dipertahankan bahkan ditingkatkan menjadi lebih baik hingga memberi banyak manfaat kepada masyarakat.

Nilai strategis perpustakaan desa nyatanya tidak sejalan dengan kondisi praktis yang ada. Desa-desa yang ada, khususnya di Kabupaten Bandung Barat tidak memiliki perpustakaan desa, sekalipun memiliki namun kondisinya terbatas seperti tidak adanya buku-buku yang relevan dan terbaru, tidak adanya pustakawan, serta jauhnya akses perpustakaan dari lingkungan masyarakat dan berbagai permasalahan lainnya (Rohanda, Prahatmaja, \& Rosfiantika, 2014; Sukaesih, Witoto, \& Sumiati, 2013).

Permasalahan tersebut di atas sejalan dengan apa yang ada di Desa Cimanggu. Berdasarkan kepada fakta yang ada di Desa Cimanggu dapat dikatakan bahwa 
perpustakaan desa dahulunya ada, namun dikarenakan minimnya faktor pemeliharaan dan pengembangan, serta tidak adanya pustakawan menyebabkan perpustakaan desa menjadi tidak berjalan sebagaimana mestinya yang sudah terjadi hampir 1 (satu) tahun terakhir.

Permasalahan tersebut di atas dijadikan dasar oleh Mahasiswa Sekolah Tinggi Ilmu Admnistrasi (STIA) Cimahi untuk mengaktifkan kembali perpustakaan desa dengan mengambil tema kegiatan Taman Bacaan Masyarakat (TBM). Kegiatan pertama yang dilakukan yaitu berkoordinasi dengan pemerintah desa mengenai rencana perbaikan TBM yang bertempat di salah satu ruangan di kantor desa. Selain mahasiswa menggali permasalahan yang menjadi hambatan dalam pengembangan TBM yang dahulu ada dan tidak berjalan seperti tujuan awal, mahasiswa juga menggali potensi apabila TBM kembali dibuka dan dijalankan dengan harapan masyarakat yang ada di desa bisa mengakses informasi melalui TBM.

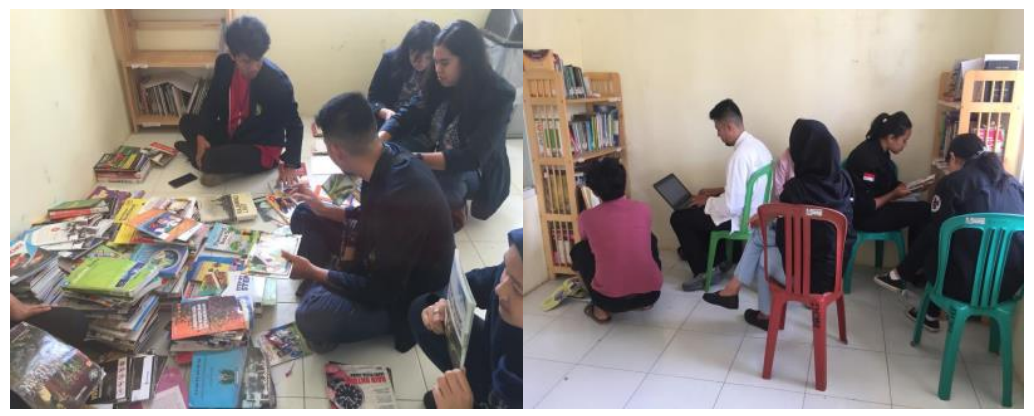

Gambar 4. Kegiatan Mahasiswa Mendata Buku di TBM

Langkah awal yang dilakukan mahasiswa setelah disetujuinya TBM yang bertempat di salah satu ruangan kantor desa yaitu mendata kebutuhan apa saja yang harus ada dalam perpustakaan desa, khususnya buku-buku penunjang kegiatan literasi masyarakat. Setelah mahasiswa mempersiapkan TBM maka langkah selanjutnya yaitu mengadakan diskusi dengan aparat desa mengenai operasional TBM, hal ini dilakukan agar TBM dapat berjalan secara optimal dalam memberikan layanan literasi kepada masyarakat, sehingga masyarakat dapat memanfaatkan perpustakaan desa sesuai dengan kebutuhannya masing-masing.

Perbaikan TBM yang dilakukan oleh mahasiswa terkendala oleh kesediaan anggaran untuk pengadaan sarana TBM seperti kursi, meja, rak buku serta komputer. Meskipun demikian pemerintah desa berkomitmen untuk menyediakan prasarana tersebut yang akan dilakukan melalui upaya pengajuan kepada pemerintah daerah Kabupaten Bandung Barat.

\section{Evaluasi Gerakan Literasi Perdesaan}

Evaluasi merupakan kegiatan untuk mengukur efek dari sebuah kebijakan yang telah ditetapkan. Dengan demikian para implementor akan mengetahui apakah tujuan awal yang telah ditetapkan dapat tercapai atau tidak (Syamsuddin, 2017; Vanbela, Fuad, \& Martini, 2018). Atas dasar pemahaman tersebut maka perlu dilakukan evaluasi terhadap gerakan literasi perdesaan yang telah dilaksanakan oleh Mahasiswa STIA Cimahi di Desa Cimanggu Kabupaten Bandung Barat.

Evaluasi gerakan literasi perdesaan dilakukan dengan menitikberatkan kepada proses dan output/hasil yang telah dicapai. Dengan demikian akan terlihat bagaimana 
proses pelaksanaan gerakan literasi perdesaan beserta kunci keberhasilan atau faktor kegagalan serta manfaat yang dirasakan dari adanya gerakan literasi perdesaan tersebut. Berikut adalah hasil evaluasi gerakan literasi perdesaan di Desa Cimanggu Kabupaten Bandung Barat.

Pertama, proses pelaksanaan gerakan literasi perdesaan secara umum dapat dikatakan berjalan dengan baik. Selama pelaksanaan program tersebut, baik mahasiswa maupun kelompok sasaran turut berpartisipasi dalam berbagai kegiatan literasi perdesaan. Kendala yang dihadapi dalam pelaksanaan literasi perdesaan yaitu keterbatasan waktu mengingat kegiatan literasi perdesaan membutuhkan waktu yang intens namun dalam praktiknya dalam satu kegiatan hanya dilaksanakan selama satu bulan.

Hal lainnya yang menjadi kendala yaitu terbatasnya sarana yang ada baik sarana yang langsung seperti ketersediaan buku yang mampu menunjang pelaksanaan gerakan literasi perdesaan, maupun sarana penunjang seperti tempat yang representatif dalam pelaksanaan literasi perdesaan. Meskipun demikian semua kegiatan dalam gerakan literasi dapat dilaksanakan dengan baik dan lancar.

Kedua, manfaat yang dirasakan dari adanya gerakan literasi perdesaan yaitu bagi pemerintah desa sudah memunculkan kesadaran akan pentingnya literasi perdesaan, diharapkan kesadaran tersebut akan ditunjukan dengan tindakan lanjutan seperti memasukan program literasi perdesaan dalam rencana pembangunan desa yang didukung dengan penyediaan sarana yang memadai. Bagi kelompok sasaran khususnya bagi anak-anak bahwa gerakan literasi perdesaan sudah mampu memberikan pemahaman akan pentingnya budaya literasi baik itu yang dilakukan di lingkungan sekolah maupun di lingkungan rumah tempat anak-anak tersebut bermain.

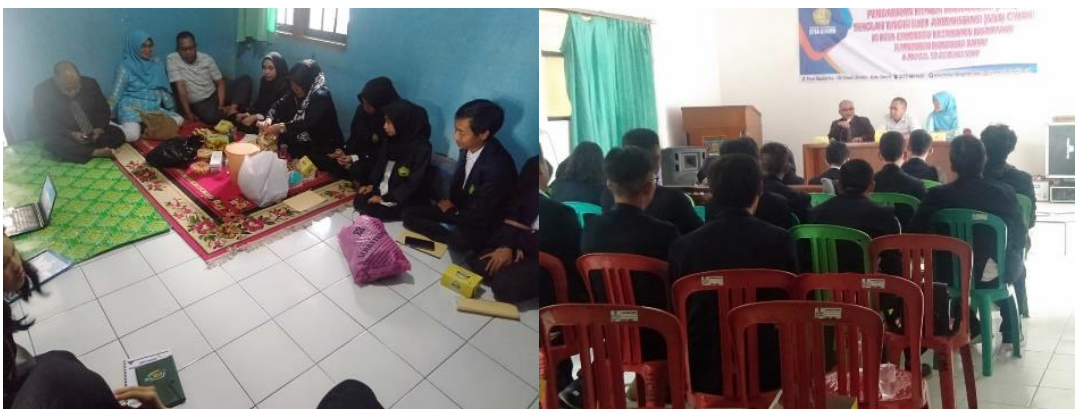

Gambar 5. Kegiatan Pengabdian Kepada Masyarakat di Desa Cimanggu

Pelaksanaan gerakan literasi perdesaan yang telah dilaksanakan oleh mahasiswa STIA Cimahi selain diharapkan dapat memberikan manfaat kepada masyarakat juga dihararapkan dapat terus dilaksanakan secara berkelanjutan oleh para pemangku kepentingan yang ada di Desa Cimanggu sehingga kegiatan literasi dapat dijadikan sebagai sebuah budaya yang memberi manfaat kepada perbaikan kualitas hidup masyarakat desa.

\section{SIMPULAN}

Gerakan literasi perdesaan yang dilaksanakan oleh Mahasiswa Sekolah Tinggi Ilmu Administrasi (STIA) Cimahi telah memberikan hasil bagi peningkatan minat dan budaya literasi yang ada di Desa Cimanggu. Kegiatan yang berhasil dilaksanakan terdiri dari 
kegiatan pemberdayaan dan kegiatan pembangunan infrastruktur penunjang literasi perdesaan. Dalam pelaksanaan kegiatan pemberdayaan, capaian kegiatan yaitu: (i) capaian kegiatan sosialisasi pentingnya literasi perdesaan yang ditujukan kepada Pemerintah Desa Cimanggu. (ii) capaian pembelajaran literasi yang dilaksanakan di lingkungan masyarakat. (iii) capaian pembelajaran dan pembimbingan literasi untuk anak-anak Sekolah Dasar (SD). Dalam pelaksanaan kegiatan pembangunan infrastruktur literasi, capaian kegiatan berupa pendataan dan perbaikan Taman Bacaan Masyarakat (TBM) yang berada di lingkungan kantor pemerintah desa.

Berdasarkan kepada simpulan tersebut di atas, maka rekomendasi bagi gerakan literasi perdesaan agar dapat berkembang dan berkelanjutan yaitu sebagai berikut: 1) Keberpihakan Pemerintah Desa Cimanggu dalam gerakan literasi perdesaan perlu ditingkatkan seperti memasukan program literasi perdesaan menjadi bagian dari program kerja tahunan pemerintah desa; 2) Gerakan literasi perdesaan akan memiliki manfaat yang lebih besar bagi masyarakat apabila disesuaikan dengan aktivitas perekonomian dan kebudayaan yang ada dan berkembang di masyarakat; dan 3) Upaya integratif antara kurikulum pendidikan dengan budaya lokal di lingkungan sekolah menjadi penting agar literasi menjadi sebuah tuntutan dan budaya bagi anak-anak yang ada di perdesaan.

\section{REFERENSI}

Adimiharja, K., \& Hikmat, H. (2003). Oarticipatory research appraisal: pengabdian dan pemberdayaan masyarakat. Bandung: Penerbit Humaniora.

Akbar, M. F., \& Anggraeni, F. D. (2017). Teknologi dalam pendidikan: Literasi digital dan selfdirected learning pada mahasiswa skripsi. Jurnal Indigenous, 2(1), 28-38.

Alam, S. (2015). Membangun Perpustakaan Desa Menjadi Peletak Dasar Lahirnya Budaya baca Masyarakat di Perdesaan. Jurnal JUPITER, 14(2), 78-82.

Andina, E. (2017). Pentingnya literasi bagi peningkatan kualitas pemuda. Majalah Info Singkat Kesejahteraan Sosial, 9(21), 9-12.

Handayani, S. (2009). Penerapan metode penelitian participatory research apraisal dalam penelitian permukiman vernakular (Permukiman kampung kota). In Seminar Nasional Penelitian Arsitektur-Metoda dan Penerapannya. Semarang: Universitas Diponegoro.

Herdiana, D. (2018). Dampak Pembangunan Perumahan Terhadap Perubahan Sosial Masyarakat Desa (Studi Kasus di Desa Jayamekar, Kabupaten Bandung Barat). Jurnal Pembangunan Wilayah Dan Kota, 14(4), 265-280.

Irianto, P. O., \& Febrianto, L. Y. (2017). Pentingnya penguasaan literasi bagi generasi muda dalam menghadapi MEA. In The 1st Education and Language International Conference Proceedings Center for International Language Development of Unissula (pp. 640-647). Semarang: Universitas Islam Sultan Agung Semarang.

Lombogia, B. J., Kairupan, B. H. ., \& Dundu, A. E. (2018). Hubungan kecanduan internet dengan kualitas tidur pada siswa SMA Kristen 1 Tomohon. Jurnal Medik Dan Rehabilitasi, $1(2), 1-8$. 
Marfu'i, L. N. R. (2016). Upaya pendukung pembelajaran literasi dengan mengasah kemampuan berfikir kritis melalui teknik bibliolearnig pada siswa. Jurnal Ilmiah Mitra Swara Ganesha, 3(2), 1-18.

Miskahuddin. (2017). Pengaruh Internet Terhadap Penurunan Minat Belajar Mahasiswa. Jurnal Mudarrisuna, 7(2), 293-312.

Nopilda, L., \& Kristiawan, M. (2018). Gerakan literasi sekolah berbasis pembelajaran multiliterasi: Sebuah paradigma pendidikan abad ke 21. Jurnal Manajemen, Kepemimpinan Dan Supervisi Pendidikan, 3(2), 216-231.

Permatasari, A. (2015). Membangun Kualitasi BAngsa dengan Budaya Literasi. In Prosiding Seminar Nasional Bulan Bahasa UNIB 2015 (pp. 146-156). Bengkulu.

Pratiwi, W. D. (2007). Participatory rural appraisal (PRA). Bandung: Institut Teknologi Bandung.

Ritonga, S., \& Andhika, W. (2012). Pengaruh media komunikasi internet terhadap pola perilaku anak di bawah umur 17 tahun. Jurnal Perspektif, 5(2), 94-100.

Rohanda, Prahatmaja, N., \& Rosfiantika, E. (2014). pembinaan perpustakaan desa di Desa Dangiang dan Dawungsari Kecamatan Cilawu Kabupaten Garut. Dharmakarya: Jurnal Aplikasi Ipteks Untuk Masyarakat, 3(257-62).

Rohidin, R. (2012). Internet dalam konteks perpustakaan. Jurnal Pustakaloka, 4(1), 1-19.

Rohman, A. S., \& Sukaesih, S. (2017). Transformasi perpustakaan desa untuk pemberdayaan masyarakat: Studi kasus di Desa Margamukti Pangalengan Bandung. Jurnal Perpustakaan Pertanian, 26(2), 47-54.

Sari, A. P., Ilyas, A., \& Ifdil. (2017). Tingkat kecanduan internet pada remaja awal. JPPI (Jurnal Penelitian Pendidikan Indonesia), 3(2), 110-117.

Silvana, H., \& Cecep. (2018). Pendidikan literasi digital di kalangan usia muda di Kota Bandung. Pedagogia: Jurnal Ilmu Pendidikan, 16(2), 146-156.

Sukaesih, Witoto, \& Sumiati. (2013). Pembinaan perpustakaan desa di Kampung Cirendeu Kelurahan Leuwigajah Kecamatan Cimahi Selatan. Dharmakarya: Jurnal Aplikasi Ipteks Untuk Masyarakat, 2(2), 99-106.

Suragangga, I. M. N. (2017). Mendidik lewat literasi untuk pendidikan berkualitas. Jurnal Penjaminan Mutu, 3(2), 154-163.

Syamsuddin. (2017). Evaluasi kebijakan ketertiban umum di Kota Palu (Studi kasus perda nomor 21 tahun 1998 tentang larangan perbuatan prostitusi dan praktik tuna susila dalam wilayah Kotamadya Palu). EJurnal Katalogis, 5(12), 185-191.

Vanbela, V. T., Fuad, N., \& Martini, A. (2018). Evaluasi program gerakan literasi sekolah di SDN Rorotan 05 Kota Jakarta Utara. Indonesian Journal of Primary Education, 2(2), 1-13.

Wandasari, Y. (2017). Implementasi gerakan literasi sekolah (GLS) sebagai pembentuk pendidikan berkarakter. Jurnal Manajemen, Kepemimpinan Dan Supervisi Pendidikan, 1(1), 325-343.

Yusup, P. M., \& Saepuddin, E. (2017). Nilai-nilai praksis perpustakaan desa dan perpustakaan masyarakat di Jawa Barat. Record and Library Journal, 3(2), 172-188.

Zaidannas, A. (2017). Kesenjangan pendidikan literasi digital dengan kemudahan akses internet. Retrieved April 27, 2019, from http://projectchild.ngo/blog/2017/08/07/kesenjanganpendidikan-literasi-digital-dengan-kemudahan-akses-internet 